\title{
Karakter Agronomi dan Potensi Hasil 10 Genotipe Padi Tipe Baru pada Dua Lingkungan Tumbuh Berbeda
}

\section{Agronomic Characteristics and Yield Potential of 10 Genotypes of New Rice Type on Two Different Agroecologies}

\author{
Dulbari $^{1 *}$, Nyimas Sa'diyah ${ }^{2}$, Muhammad Kamal ${ }^{2}$, dan Gut Tianigut ${ }^{1}$ \\ ${ }^{1}$ Jurusan Budidaya Tanaman Pangan, Politeknik Negeri Lampung. Jln. Soekarno Hatta No. 10 \\ Rajabasa Bandar Lampung, 35144 \\ ${ }^{2}$ Jurusan Agroekoteknologi Fakultas Pertanian, Universitas Lampung. Jln. Prof. Soemantri \\ Brodjonegoro, No. 1 Bandar Lampung 35145 \\ *Email: dulbari23@yahoo.co.id
}

\begin{abstract}
The purpose of this study was to evaluate the agronomic characters and yield potential of ten new plant type (NTP) of rice genotypes planted on two different agroecologies. The study was done in East Lampung (Ultisols soil type, altitude $60 \mathrm{~m}$ asl, and average daily temperature $26,86^{\circ} \mathrm{C}$ ) and Tanggamus (Andisols soil type, altitude $600 \mathrm{~m}$ asl, and average daily temperature $24.15^{\circ} \mathrm{C}$ ) in January-Juni. The research was arranged in randomized complete block design (RCBD) with 12 treatments and 3 replications. The treatment consisted of 10 new type of rice genotypes, i.e., IPB 3S, IPB 4S, IPB 5R, IPB6R, IPB117-F-7-2-1, IPB 117-F-7-71, IPB 117-F-14-4-1, IPB 117-F-15-4-1, IPB 117-F-20-1-1, IPB 117-F-80- 2-1, and two varieties, i.e., Ciliwung and Ciherang as control. The results showed that all NPT genotypes had lower number of tillers but the hill height were taller than the Ciliwung and Ciherang varieties. Eight genotypes had a faster harvesting time, and one genotype had a higher yield than two control varieties.
\end{abstract}

Keywords: agronomic character, yield potential, new plant type of rice, agroecology

Disubmit: 30 Desember 2017, Diterima: 14 Januari 2018, Disetujui: 31 Januari 2018

\section{PENDAHULUAN}

Penggunaan benih padi varietas unggul berpengaruh terhadap produktivitas tanaman. Varietas padi yang mempunyai potensi hasil tinggi terus dikembangan untuk meningkatkan hasil petani. Pengembangan varietas padi dengan potensi hasil tinggi sudah lama dilakukan. Tahun 1989, Lembaga Penelitian Padi Internasional atau International Rice Research Institute (IRRI) mempelopori perakitan padi dengan arsitektur baru yang kemudian dikenal dengan istilah New Plant Type of Rice (NPT) atau Padi Tipe Baru (PTB). Penelitian ini diilhami oleh Donald tahun 1968 melalui pendekatan pemuliaan idiotipe (Yang et al., 2006). PTB dicirikan dengan karakter anakan lebih sedikit, semua anakan produktif, bermalai lebat (200-250 gabah per malai), bernas, tinggi tanaman sedang $(90-100 \mathrm{~cm})$, dan berbatang kokoh, daun tegak, tebal, dan berwarna hijau tua, perkaran lebat dan dalam, berumur sedang (110 - 130 hari), serta tahan hama dan penyakit (Khush, 2001). Karakeristik tersebut ditujukan untuk meningkatkan potensi hasil 20-25\% (Khan et al., 2015). Selain karakter tersebut, peningkatan potensi hasil PTB juga dapat dilakukan dengan meningkatkan jumlah malai per $\mathrm{m}^{2}$, jumlah gabah per malai, bobot gabah isi, total biomas, dan indeks panen (Peng et al., 2008).

Pembentukan PTB di Indonesia dimulai tahun 1995 dengan mengintrodusi beberapa galur NPT dari IRRI generasi pertama. Penelitian lebih intensif baru dilakukan tahun 2001 yang berhasil melepas beberapa 
Dulbari dkk : Karakter Agronomi dan Potensi Hasil 10 Genotipe Padi Tipe Baru pada Dua Lingkungan Tumbuh...

varietas antara lain Cimelati, Gilirang, Ciapus, dan Fatmawati. Namun varietas tersebut masih mempunyai beberapa kekurangan antara lain: persen gabah hampa tinggi, dan tidak tahan hama penyakit utama sehingga potensi hasil yang diharapkan belum sesuai (Abdullah et al., 2008). Sampai saat ini penelitian dan pengembangan PTB masih terus dilakukan Setiobudi et al. (2008) dan Rahmah and Aswidinnoor (2013).

Salah satu tahap pengembangan PTB adalah pengujian galur-galur terpilih pada lingkungan tumbuh (agroekologi) berbeda. Uji adaptasi dan daya hasil diperlukan untuk mengetahui potensi genetik yang dimiliki. Keragaan genotipe dipengaruhi faktor genetik, lingkungan, dan interaksi antara genetik x lingkungan. Respon genotipe yang spesifik terhadap lingkungan mengakibatkan adanya interaksi antara genotipe dan lingkungan (G x L), interaksi dapat melipatgandakan potensi genetik yang dimiliki genotipe (Gomez and Gomez, 1984). Beberapa karakter agronomi yang dapat dijadikan bahan evaluasi antara lain: tinggi tanaman, jumlah anakan, umur tanaman, komponen hasil dan potensi hasil. Penelitian uji daya hasil sudah banyak dilakukan (Syuriani et al., 2013); (Kartahadimaja et al., 2016); dan et al. (2008). Penelitian bertujuan untuk mengetahui penampilan karakter agronomi dan potensi hasil beberapa genotipe PTB yang ditanam pada kondisi agroekologi berbeda.

\section{METODE PENELITIAN}

Penelitian dilakukan pada bulan Januari-Juni di dua lokasi. Lokasi pertama, desa Banjarrejo Kecamatan Batanghari Kabupaten Lampung Timur ketinggiaan $60 \mathrm{~m}$ dpl, jenis tanah ultisol, dengan suhu rata harian $26,86{ }^{\circ} \mathrm{C}$. Lokasi kedua, desa Wonorejo Kecamatan Sumberrejo Kabupaten Tanggamus dengan ketinggian $600 \mathrm{~m}$ dpl, jenis tanah andosol, dengan suhu rata-rata harian $24,15^{\circ} \mathrm{C}$. Jarak antara dua lokasi penelitian \pm 150 $\mathrm{km}$.

Percobaan disusun menggunakan Rancangan Kelompok Teracak Sempurna (RKTS) menggunakan perlakuan faktor tunggal dengan 3 ulangan. Perlakuan terdiri dari 10 genotiep PTB yaitu : 1) IPB 3S, 2) IPB 4S, 3) IPB 5R, 4) IPB 6R, 5) IPB 117-F-7-2-1, 6) IPB 117-F-7-7-1, 7) IPB 117-F-14-4-1, 8) IPB 117-F-15-41, 9) IPB 117-F-20-1-1, 10) IPB 117-F-80-2-1, selanjutnya disebut G1, G2, G3, G4, G5, G6, G7, G8, G9, G10 dan 2 varietas unggul nasional Ciliwung dan Ciherang sebagai pembanding.

Petak percobaan yang digunakan berukuran $3 \mathrm{~m}$ x $4 \mathrm{~m}$ sebanyak 36 petak di setiap lokasi. Penanaman menggunakan bibit berumur 21 hari, ditanam dengan sedalam 1-2 cm dengan jarak tanam $25 \mathrm{~cm} \times 25 \mathrm{~cm}, 2$ 3 batang per rumpun. Dosis pupuk yang digunakan Urea $300 \mathrm{~kg} \cdot \mathrm{ha}^{-1}, \mathrm{SP} 36200 \mathrm{~kg} \cdot \mathrm{ha}^{-1}, \mathrm{KCl} 100 \mathrm{kgha}^{-1}$. Pupuk dasar diberikan pada saat tanam terdiri dari 1/3 dosis pupuk Urea, seluruh dosis pupuk SP36 dan KCl. Pupuk Urea susulan diaplikasikan pada saat tanaman berumur 3 minggu setelah tanam 1/3 dosis, dan susulan kedua umur 6 minggu setelah tanam 1/3 dosis. Pengendalian gulma dilakukan dengan cara manual sebanyak 2 kali umur 3 dan 6 mst. Pengendalian hama dilakukan menggunakan pestisida berbahan aktif karbofuran dan dimehipo sesuai anjuran.

Pengamatan dilakukan pada 10 tanaman sampel yang ditentukan secara acak pada setiap petak percobaan. Peubah agronomi yang diamati adalah: tinggi tanaman, jumlah anakan produktif, bobot kering brangkasan, bobot gabah per malai, umur panen dan potensi hasil yang dihitung menggunakan persamaan :

$$
\begin{aligned}
& \mathrm{GKP}=\frac{\text { bobot hasil } 20 \text { rpn }}{20 r p n} \times \text { pop.per hektar } \\
& \text { GKG }(\text { KA } 14 \%)=\frac{100-\text { KA panen }}{100-14} \times \mathrm{GKP}
\end{aligned}
$$

Keterangan : GKP = gabah kering panen, $\mathrm{GKG}=$ gabah kering giling, $\mathrm{KA}=$ kadar air. 
Data hasil pengamatan dianalisis keragaman menggunakan uji Barlet, bila memenuhi asumsi dilanjutkan dengan uji F secara serentak untuk masing-masing lokasi. Perbedaan perlakuan ditentukan dengan uji Less Significant Increase (LSI) taraf 5\%.

\section{HASIL DAN PEMBAHASAN}

Kondisi Umum. Secara umum kondisi tanaman di kedua lokasi penelitian cukup baik, semua genotipe dapat tumbuh dan berkembang dengan sempurna. Pengaruh lingkungan terlihat pada perbedaan laju pertumbuhan tanaman dimana tanaman padi yang ditanam di lokasi Lampung Timur secara keseluruhan mempunyai umur berbunga dan umur panen lebih cepat dibandingkan dengan pertanaman di Tanggamus (data pengamatan umur berbunga dan umur panen).

Terjadinya perbedaan umur tanaman diduga akibat adanya perbedaan agroekologi lokasi penanaman terutama perbedaan suhu rata-rata harian (Lampung Timur $26,86^{\circ} \mathrm{C}$ dan Tanggamus $24,15^{\circ} \mathrm{C}$ ). Tanaman padi dapat tumbuh pada kisaran suhu rata-rata bulanan $15-35^{\circ} \mathrm{C}$ (Chakraborty, 2001). Perbedaan suhu mempengaruhi karakteristik pertumbuhan tanaman (umur berbunga dan umur panen). Suhu berpengaruh terhadap metabolisme pertumbuhan tanaman. Pada kisaran suhu optimal tanaman padi akan tumbuh dengan normal. Suhu yang tinggi akan mengganggu proses metabolisme tanaman (Peng et al., 2004).

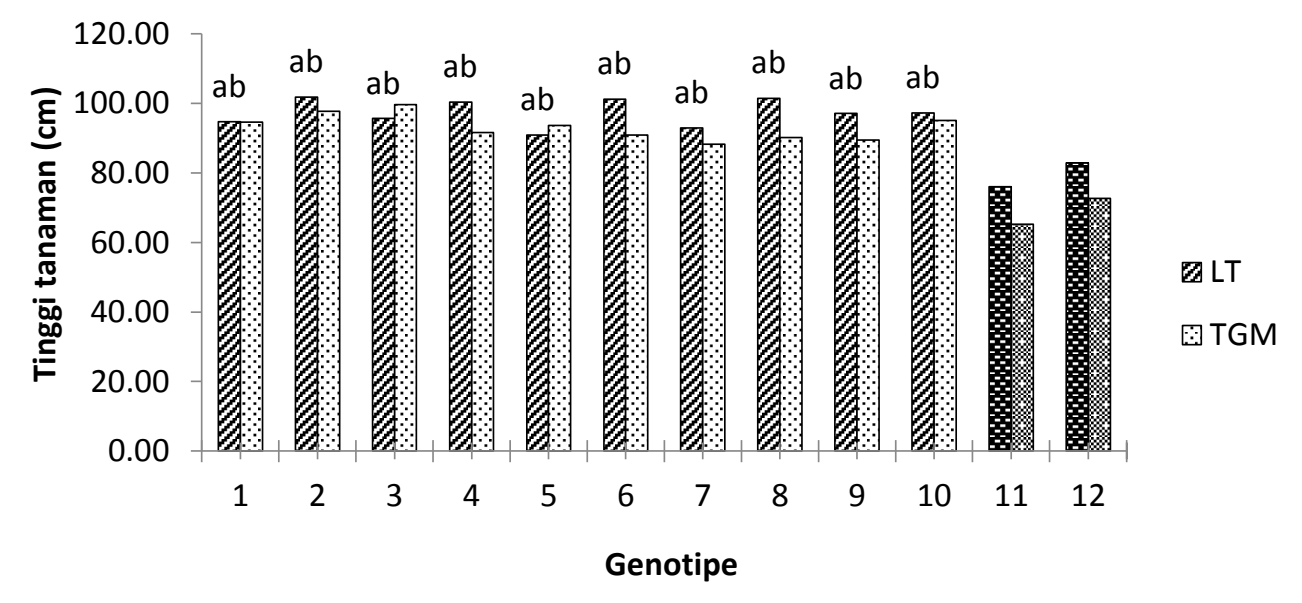

Gambar 1. Keragaan tinggi tanaman genotipe PTB pada dua lingkungan tumbuh berbeda, LT: Lampung Timur, TGM: Tanggamus, ab: nyata lebih tinggi dari varietas pembanding (Ciliwung dan Tanggamus) Uji LSI taraf 5\%. 1: G1, 2: G2, 3: G3, 4: G4, 5: G5, 6: G6, 7: G7, 8: G8, 9: G9, 10: G10, 11: Ciliwung, 12: Ciherang.

Karakter Agronomi dan Potensi Hasil. Keragaan karakter agronomi dan potensi hasil genotipe yang diuji menunjukkan perbedaan yang nyata pada Uji LSI taraf 5\% dan 1\%. Karakter tinggi tanaman 10 genotipe yang diuji di kedua lokasi berbeda nyata dengan tanaman pembanding (Ciliwung dan Ciherang) pada taraf 5\%. Di Lampung Timur 4 genotipe mempunyai tinggi tanaman rata-rata di atas $100 \mathrm{~cm}$ yaitu: G2 (101,87 cm), G4 $(100,33 \mathrm{~cm})$, G6 $(101,23 \mathrm{~cm})$ dan G8 $(101,47 \mathrm{~cm})$. Di Tanggamus tidak ada genotipe yang mencapai tinggi tanaman rata-rata diatas $100 \mathrm{~cm}$. Keragaan karakter tinggi tanaman disajikan pada Gambar 1. 
Dulbari dkk: Karakter Agronomi dan Potensi Hasil 10 Genotipe Padi Tipe Baru pada Dua Lingkungan Tumbuh...

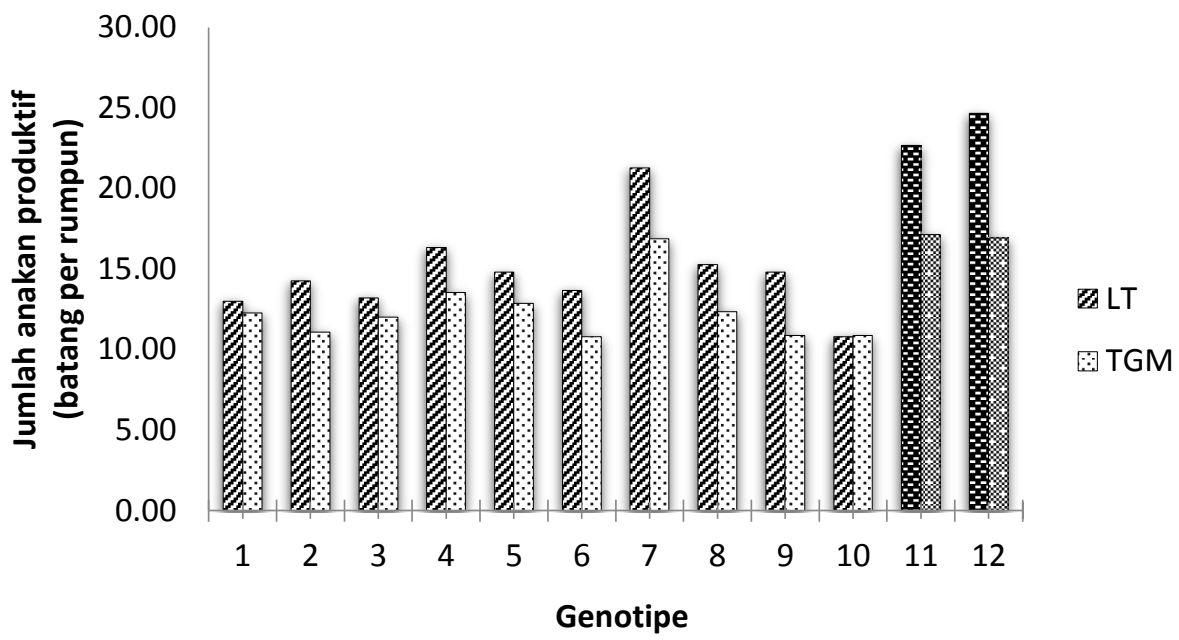

Gambar 2. Keragaan jumlah anakan produktif genotipe PTB pada dua lingkungan tumbuh berbeda. LT: Lampung Timur, TGM: Tanggamus, 1: G1, 2: G2, 3: G3, 4: G4,5: G5, 6: G6, 7: G7, 8: G8, 9: G9, 10: G10, 11:Ciliwung, 12: Ciherang.

Karakter jumlah anakan produktif 10 genotipe yang diuji tidak ada yang melebihi jumlah anakan varietas pembanding (Ciliwung dan Ciherang). Jumlah anakan produktif Ciliwung dan Ciherang di Lampung Timur : 31 dan 27, sementara di Tanggamus 29 dan 30. Keragaan karakter jumlah anakan ditampilkan pada Gambar 2 .

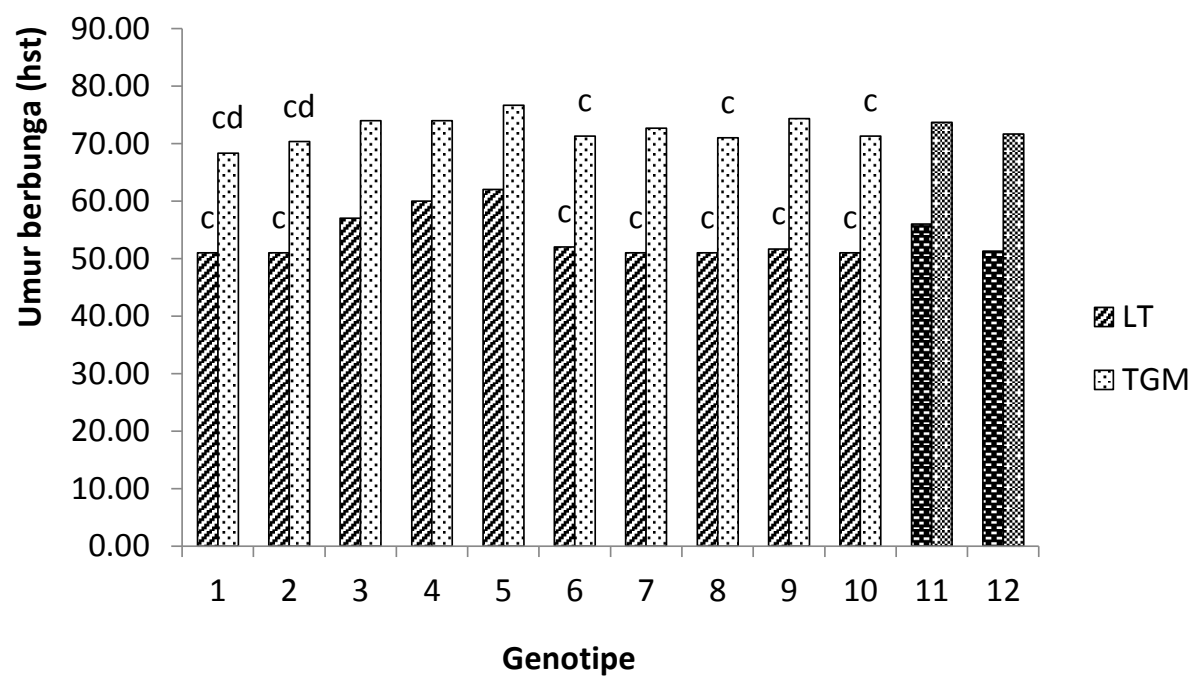

Gambar 3, Keragaan umur berbunga gonotipe PTB pada dua kondisi lingkungan tumbuh berbeda LT: Lampung Timur, TGM: Tanggamus, c: nyata lebih cepat dibandingkan varietas Ciliwung, d: nyata lebih cepat dibandingkan varietas Ciherang pada Uji LSI taraf 5\%,1: G1, 2: G2, 3: G3, 4: G4,5: G5, 6: G6, 7: G7, 8: G8, 9: G9, 10: G10, 11:Ciliwung, 12: Ciherang.

Keragaan karakter umur berbunga dan umur panen di kedua lokasi menunjukkan perbedaan yang nyata. Rata-rata umur panen genotipe yang ditanam di Lampung Timur adalah 92,75 hari setelah tanam (hst). Dari rata-rata umur panen 10 genotipe yang diuji, 8 genotipe mempunyai umur lebih cepat dari varietas Ciliwung dan Ciherang. Delapan genotipe tersebut adalah : G1 = 88,67 hst, G2= 92 hst, G3=92 hst, G6=91,33 hst, 
G7 $=92,67$ hst, G8=89,33 hst, G9=92 hst, dan G10=91,33 hst. Keragaan karakter umur berbunga disajikan pada Gambar 3.

Rata-rata umur berbunga dan umur panen genotipe yang ditanam di Tanggamus lebih lama jika dibandingkan dengan genotipe yang ditanam di Lampung Timur. Genotipe padi sawah yang ditanam di Tanggamus rata-rata berbunga pada umur $72 \mathrm{hst}$ dan dipanen pada umur 103,72 hst. Terdapat dua genotipe yang mempunyai umur berbunga dan umur panen lebih cepat dari Ciliwung dan Ciherang yaitu : G1=68,33 hst dan 99,00 hst serta G2=70,33 hst dan 99,33 hst.Umur panen genotipe di Lampung Timur lebih cepat dibandingkan dengan umur panen genotipe di Tanggamus, hal ini diduga karena adanya perbedaan suhu ratarata harian dari kedua lokasi tersebut. Suhu tinggi menyebabkan proses penuaan berjalan lebih cepat hal ini dicirikan dengan adanya klorosis dan kemasakan dini pada bulir dan menurunkan produksi (Peng et al., 2004). Keragaan umur panen disajikan pada Gambar 4.

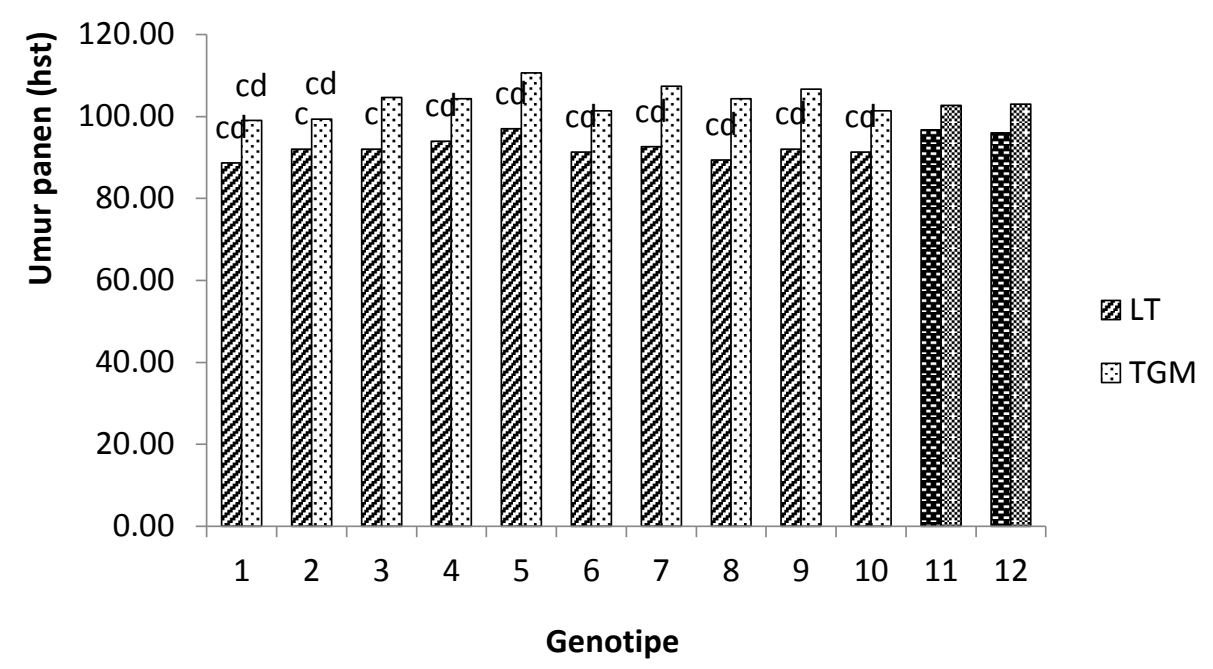

Gambar 4. Keragaan umur panen genotipe PTB pada dua lingkungan tumbuh berbeda, LT: Lampung Timur, TGM: Tanggamus, c: nyata lebih cepat dari varietas Ciliwung, d: nyata lebih cepat dari varietas pembanding Tanggamus pada Uji LSI taraf 5\%. 1: G1, 2: G2, 3: G3, 4: G4, 5: G5, 6: G6, 7: G7, 8: G8, 9: G9, 10: G10, 11: Ciliwung, 12: Ciherang.

Bobot kering brangkasan genotipe G7 di Lampung Timur nyata lebih berat dibandingkan kontrol Ciliwung. Di Tanggamus genotipe G5 mempunyai bobot kering brangkasan nyata lebih berat dibandingkan dengan kontrol Ciherang. Keragaan karakter bobot kering krangkasan ditampilkan pada Gambar 5. 


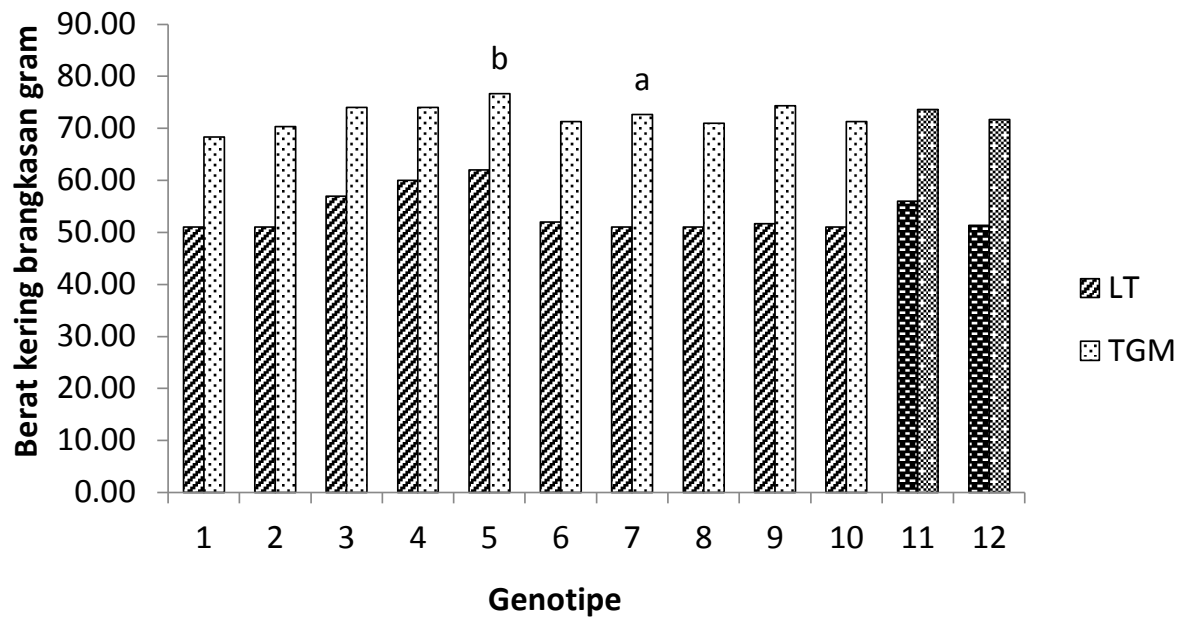

Gambar 5. Keragaan bobot kering brangkasan genotipe PTB pada dua lingkungan tumbuh berbeda, LT: Lampung Timur, TGM: Tanggamus, a: nyata lebih berat dari varietas Ciliwung, b: nyata lebih cepat dari varietas Tanggamus pada Uji LSI taraf 5\%. 1: G1, 2: G2, 3: G3, 4: G4, 5: G5, 6: G6, 7: G7, 8: G8, 9: G9, 10: G10, 11: Ciliwung, 12: Ciherang.

Keragaan karakter bobot gabah per malai masing-masing genotipe di kedua lokasi menunjukkan perbedaan yang nyata pada gabungan taraf $1 \%$. Rata-rata bobot gabah per malai di lokasi Lampung Timur adalah 4,8 gram, sedangkan di lokasi Tanggamus adalah 6,46 gram. Dari 10 genotipe yang diuji di kedua lokasi hampir semua mempunyai bobot gabah per malai nyata lebih tinggi dibandingkan dengan bobot gabah per malai varietas Ciliwung maupun Ciherang pada uji LSI taraf 5\%, kecuali genotipe G1 dengan bobot 3,93 g dan G7 dengan bobot 4,05 gdi lokasi Lampung Timur, dan bobot gabah per malai G7 4,98 g di Tanggamus. Bobot gabah per malai tertinggi untuk lokasi Lampung Timur terdapat pada genotipe G4 dengan 6,45 g dan di Tanggamus genotipe G2sebesar 7,91 g.

Adanya perbedaan keragaan karakter bobot gabah per malai di kedua lokasi menunjukkan adanya pengaruh lingkungan. Hasil pengujian menunjukkan bahwa bobot rata-rata per malai di Tanggamus (6,46 g) lebih tinggi dibandingkan dengan Lampung Timur (4,80 gram). Karakter bobot gabah per malai merupakan salah satu komponen hasil tanaman padi, karakter ini dipengaruhi oleh periode akumulasi biomassa selama pertumbuhan. Karakter bobot gabah menentukan potensi hasil Purohit \& Majumder (2009); Yang et al. 2007). Semakin lama umur tanaman maka hasil panen tanaman semakin besar (Rahmah, 2011). Hal ini berhubungan dengan kondisi suhu rata-rata bulannya. Menurut Stone (2001) suhu tinggi akan berpengaruh terhadap laju perkembangan tanaman. Semakin tinggi suhu maka laju perkembangan tanaman akan semakin meningkat tetapi mengurangi potensi akumulasi biomassanya. Pada tanaman serealia termasuk padi, suhu yang tinggi mempengaruhi laju perkembangan bulir menjadi lebih cepat dan bobot bulir menjadi berkurang akibat berkurangnya akumulasi pati.

Cekaman suhu tinggi dapat mempersingkat periode perkembangan tanaman sehingga menghasilkan ukuran malai lebih rendah, siklus hidup lebih pendek, dan terganggunya proses yang berkaitan dengan asimilasi karbon, akibatnya hasil panen berkurang (Maestri et al., 2002). Keragaan karakter bobot gabah per malai masing-masing genotipe ditampilkan pada Gambar 6.

Keragaan karakter potensi hasil genotipe PTB di Lampung Timur berbeda nyata dengan varietas pembanding. Genotipe G4 (10,02 ton.ha $\left.{ }^{-1}\right)$ nyata lebih tinggi dari genotipe pembanding Ciliwung dan Ciherang. Enam genotipe lainnya mempunyai potensi hasil rata-rata $>8,00$ ton.ha ${ }^{-1}$. Genotipe-genotipe tersebut adalah G2 : 8,60 ton.ha ${ }^{-1}$, G3 : 8,46 ton.ha ${ }^{-1}$, G5 : 8,05 ton.ha ${ }^{-1}$, G6 : 8,63 ton.ha ${ }^{-1}$, G8 : 8,42 ton.ha ${ }^{-1}$, dan G10 : 8,07 ton.ha ${ }^{-1}$. Karakter potensi hasil di Tanggamus menunjukkan tidak terdapat perbedaan yang 
nyata antar genotipe, begitu pula tidak ada genotipe mempunyai daya hasil nyata lebih tinggi dari kedua varietas pembanding. Namun potensi hasil rata-ratanya mencapai 9,21 ton.ha ${ }^{-1}$. Karakter potensi hasil genotipe PTB pada dua agroekologi ditampilkan pada Gambar 7.

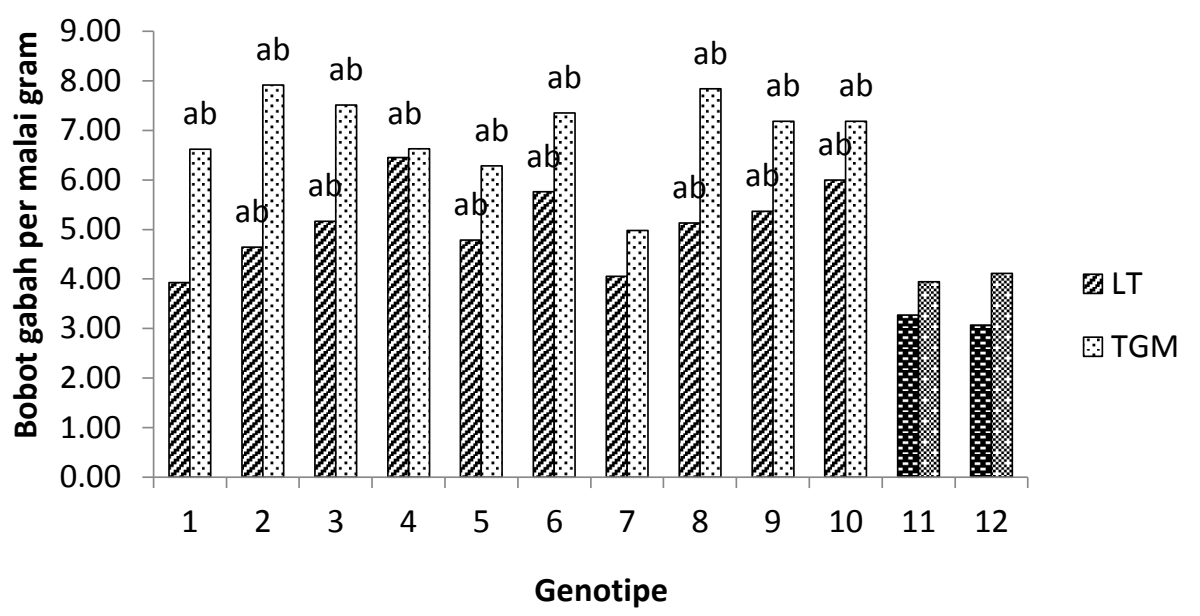

Gambar 6. Keragaan bobot gabah per malai genotipe PTB pada dua lingkungan tumbuh berbeda, LT: Lampung Timur, TGM: Tanggamus, ab: nyata lebih tinggi dari varietas Ciliwung dan Tanggamus pada Uji LSI taraf 5\%. 1: G1, 2: G2, 3: G3, 4: G4, 5: G5, 6: G6, 7: G7, 8: G8, 9: G9, 10: G10, 11: Ciliwung, 12: Ciherang.

Perbedaan potensi hasil genotipe PTB pada kedua agroekologi menunjukkan bahwa karakter potensi hasil ditentukan oleh faktor lingkungan (Yakub et al., 2012). Karakter potensi hasil yang ditunjukkan oleh 10 genotipe TPB yang diuji menggambarkan bahwa genotipe tersebut masuk ke dalam kelompok genotipe yang mempunyai daya hasil tinggi (Astarini, 2008).

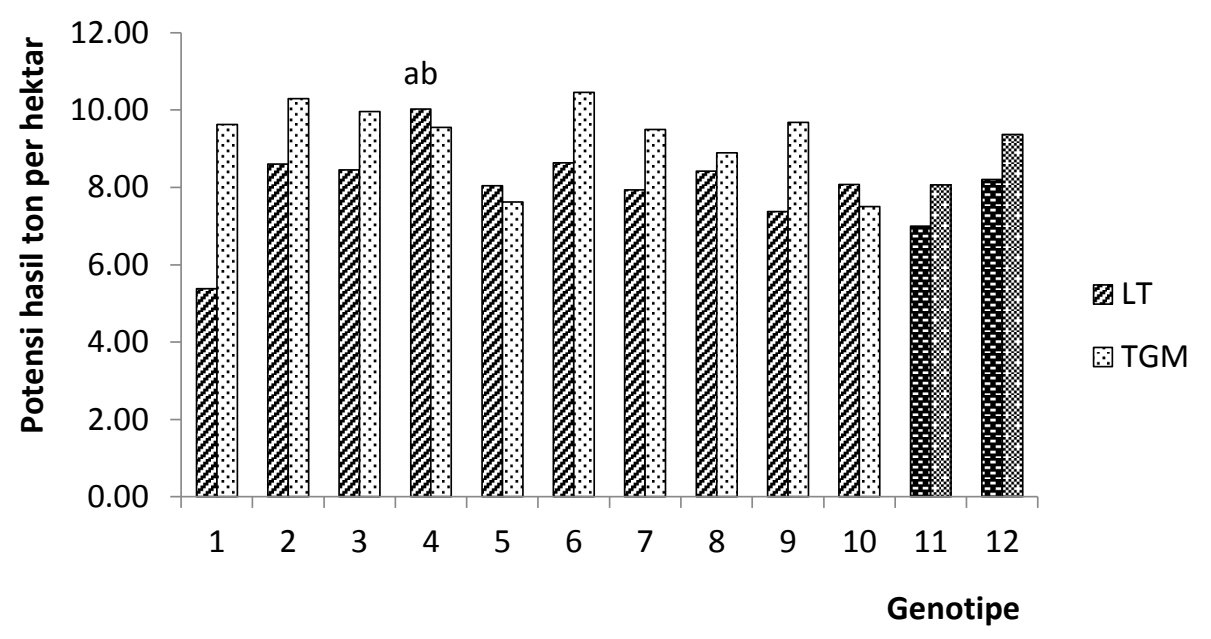

Gambar 7. Keragaan potensi hasil 10 genotipe PTB pada dua lingkungan tumbuh berbeda, LT: Lampung Timur, TGM: Tanggamus, ab: nyata lebih tinggi dari varietas Ciliwung dan Tanggamus pada Uji LSI taraf 5\%. 1: G1, 2: G2, 3: G3, 4: G4, 5: G5, 6: G6, 7: G7, 8: G8, 9: G9, 10: G10, 11: Ciliwung, 12: Ciherang. 
Dulbari dkk : Karakter Agronomi dan Potensi Hasil 10 Genotipe Padi Tipe Baru pada Dua Lingkungan Tumbuh...

\section{KESIMPULAN}

Sepuluh genotipe PTB yang diuji memiliki ukuran batang atau rumpun lebih tinggi dibandingkan dua varietas pembanding. Genotipe G1, G4, G5, G6, G7, G8, G9, dan G10 mempunyai umur panen lebih cepat dibandingkan varietas Ciliwung dan Ciherang. Genotipe G1 dan G3 lebih cepat dari Ciliwung di lokasi Lampung Timur, sedangkan genotipe G1 dan G2 mempunyai umur panen lebih cepat dibandingkan varietas Ciliwung dan Ciherang di lokasi Tanggamus. Genotipe G4 mempunyai daya hasil lebih tinggi dibandingkan varietas Ciliwung dan Ciherang di lokasi Lampung Timur. Di Tanggamus tidak terdapat genotipe PTB yang mempunyai daya hasil lebih tinggi dari varietas pembanding, namun rata-rata umum potensi hasilnya lebih tinggi dibandingkan Lampung Timur.

\section{UCAPAN TERIMAKASIH}

Ucapan terimakasih disampaikan kepada TIM DEMPLOT VITADEGRA Politeknik Negeri Lampung yang telah memberikan dukungan pendanaan pada kegiatan penelitian ini. Ucapan terimakasih juga disampaikan kepada Agrohort IPB. yang telah berkenan memberikan 10 genotipe PTB untuk penelitian ini.

\section{DAFTAR PUSTAKA}

Abdullah, B., Tjokrowidjojo, S., Sularjo, S., 2008. Perkembangan dan prospek perakitan padi tipe baru di Indonesia. J. Litbang Pertan. 27, 1-9.

Astarini, I.., 2008. Pemuliaan Tanaman Serealia [WWW Document]. URL www.fp.unud.ac.id/biotek/wpcontent/uploads/2008/.../6-serealia.ppt

Chakraborty, S., 2001. Rice Breeding and Genetics, First Edit. ed. Concept Publishing Company, India.

Gomez, K.A., Gomez, A.A., 1984. Statistical Procedures for Agricultural Research, Second Edi. ed. John Willey \& Sons, Inc, United States of America.

Kartahadimaja, J., Syuriani, E.., Apriyani, M., 2016. Potensi kuantitatif dan kualitatif 10 galur unggul baru padi jenis Pandanwangi. J. Penelit. Pertan. Terap. 16, 109-113.

Khan, M.H., Dar, Z.A., Dar, S.A., 2015. Breeding Strategies for Improving Rice Yield-A Review. Agric. Sci. $6,467-478$.

Khush, G.., 2001. New plant type of rice for increasing the genetic yield potential, in: Nanda, J.. (Ed.), Rice Breeding and Genetics. Science Publishers. Inc, USA, pp. 99-108.

Maestri, E., Klueva, N., Perrotta, C., Gulli, M., Nguyen, H.T., Marmiroli, N., 2002. Moleculler Genetics of Heat Tolerance and Heat Shock Protein in Cereals. Plant Mol. Biol. 48, 667-681.

Peng, S., Huang, J., Sheehy, J.E., Laza, R.C., Visperas, R.M., Zhong, X., Centeno, G.S., Khush, G.S., Cassman, K.G., 2004. Rice yields decline with higher night temperature from global warming. PNAS 101, 9971-9975. https://doi.org/www.pnas.org/cgi/doi/10.1073/pnas.0403720101

Peng, S., S.Khush, G., Virk, P., Tang, Q., Zou, Y., 2008. Progress in ideotype breeding to increase rice yield potential. F. Crop. Res. 108, 32-38. https://doi.org/https://doi.org/10.1016/j.fcr.2008.04.001

Purohit, S., Majumder, M.K., 2009. Selection of High Yielding Rice Variety from a Cold Tolerant Three-Way Rice (Oryza sativa L.) Cross Involving Indica, japonica and Wide Compatible Variety. Middle-East J. Sci. Res. 4, 28-31.

Rahmah, 2011. Keragaman genetik dan adaptabilitas gandum (Triticum aestivum L.) introduksi di lingkungan tropis. Institut Pertanian Bogor. 
Rahmah, R., Aswidinnoor, H., 2013. Uji Daya Hasil Lanjutan 30 Galur Padi Tipe Baru Generasi F6 Hasil dari 7 Kombinasi Persilangan. Bul. Agrohorti $1, \quad 1-8$. https://doi.org/http://dx.doi.org/10.29244/agrob.1.4.1-8

Setiobudi, D., Abdullah, B., Sembiring, H., Wardana, L.P., 2008. Peningkatan hasil padi tipe baru melalui pengelolaan hara pupuk N, in: Prosiding Simposium V Tanaman Pangan. Pusat Penelitian dan Pengembangan Tanaman Pangan, pp. 346-353.

Stone, P., 2001. The effects of heat stress on cereal yield and quality, in: AS, B. (Ed.), Crop Responses and Adaptations to Temperature Stress. Food Products Press, Binghamton NY, pp. 243-291.

Syuriani, E.E., Wentasari, R., Kartahadimaja, J., 2013. Uji daya hasil sepuluh galur baru padi (Oryza sativa. L) rakitan Politeknik Negeri Lampung. J. Penelit. Pertan. Terap. 13, 174-179.

Yakub, S.., Kartina, A.., Isminingsih, S., Suroso, M.L., 2012. Pendugaan parameter genetik hasil dan komponen hasil galur-galur padi lokal asal banten. J. Agrotopika 17, 1-6.

Yang, W., Peng, S., Laza, R.C., Visperas, R.M., Dionisio-Sese, M.L., 2006. Grain yield and yield attribute of new plant type and hybrid rice. Crop Sci. 47, 13931400. 